\title{
Plasminogen Activator Inhibitor-1 and Transforming Growth Factor $\beta 2$ in the Aqueous Humour of Patients with and without Glaucoma
}

\author{
Mona A. Abdel Hamid*, Iman A. Fahmy, ${ }^{* *}$ Ahmed Y. Helal** \\ Medical Biochemistry* and Ophthalmology Departments** \\ Research Institute of Ophthalmology
}

\begin{abstract}
This study was performed to determine the levels of plasminogen activator inhibitor-1 (PAI-1), transforming growth factor 32 (TGFß2) and total protein in the aqueous humour of patients with glaucoma versus those without glaucoma. A total of 30 aqueous humour samples were collected from patients with glaucoma and cataract (20 glaucoma aqueous samples and 10 cataract aqueous samples). The levels of PAI1 and TGFß2 were determined by enzyme linked immunosorbent assay (ELISA), while total protein levels by the Bradford method. There was a significant increase in the aqueous levels of PAI-1, TGFB2 and total protein in the glaucoma group compared to the cataract group. Further analysis of the glaucoma group showed a significant increase in the levels of PAI-1, TGFß2 in patients with late compared to patients with early open angle glaucoma. There was a significant positive correlation between the levels of PAI-1 and total protein in patients with glaucoma. Also a significant positive correlation was detected between PAI-1 and TGFß2 in both glaucoma groups. These data are consistent with the possibility that intraocularly produced PAI-1 may contribute to glaucoma pathogenesis. So, reducing the production or activity of PAI-1 in the eye could constitute a new target for the design of glaucoma therapy.
\end{abstract}

\section{INTRODUCTION}

Elevation of the intraocular pressure (IOP) is recognized as the major causal risk factor for the progression of glaucoma, which is the leading cause of blindness ${ }^{(\mathbf{1})}$. It is generally accepted that IOP elevation results from an involutional process occurring in the anterior chamber, which obstructs the aqueous outflow $^{(2)}$. The molecular mechanisms explaining the aqueous flow and IOP are not well understood yet. It is conceivable that the IOP could be controlled in part through genes that are expressed in the eye, specifically in the ciliary body and trabecular meshwork which is involved in the aqueous production and outflow. To this group of genes belongs the gene encoding PAI- $1^{(3)}$.

PAI-1 is an inducible secreted protein that belongs to the serpin (serine protease inhibitors) superfamily ${ }^{(4)}$. It constitutes a central component of the fibrinolytic system that maintains the patency of the vascular bed and other vascular structures $^{(5)}$. PAI-1 is the principle physiological inhibitor of the tissue type plasminogen activator, which 
specifically converts the inactive zymogen plasminogen into plasmin ${ }^{(6)}$. The latter is a non specific trypsinlike protease that degrades fibrin and is involved in extracellular proteolysis by degrading matrix components or activating the proenzyme of collagendegrading metallo - proteases ${ }^{(7)}$.

Elevated levels of PAI-1 have been associated with various thrombotic disorders and acute phase response such as after trauma or bacterial infection ${ }^{(8)}$. PAI-1 gene expression could be enhanced by inflammatory agents such as transforming growth factor B and interleukins $^{(\boldsymbol{9})}$.

The transforming growth factor (TGF)- $\beta$ family of cytokines includes multifunctional proteins that regulate production of a wide variety of gene products, and thus control a wide variety of cellular processes. For example, TGF- $\beta$ family members are involved in inflammation, wound healing, extracellular matrix accumulation, bone formation, tissue development, cellular differentiation, and tumor progression ${ }^{(\mathbf{1 0})}$.

Three mammalian isoforms have been identified to date: TGF- $\beta 1,-\beta 2$, and $-\beta 3$, and these isoforms are structurally similar, despite being encoded by different genes ${ }^{(11)}$. TGF- $\beta$ is a cytokine that alters extracellular matrix (ECM) metabolism, and excess ECM has been proposed to increase aqueous outflow resistance in the trabecular meshwork (TM) of glaucomatous eyes $^{(\mathbf{1 2})}$. TGF- $\beta$ appears to be involved in the pathogenesis of certain forms of glaucoma.

So, the aim of this work is to estimate the aqueous levels of PAI-1, total protein (to evaluate the origin of
PAI-1) and TGF 32 in patients with glaucoma.

\section{SUBJECTS \& METHODS}

The present study included twenty patients with primary open angle glaucoma (POAG), who were scheduled for glaucoma filtering surgery, 10 patients with early open angle glaucoma (group2) and 10 patients with late open angle glaucoma (group3).Their mean age was 63 years. Ten cataract patients, their mean age was 65 years (group1), they were used as controls. The cataract group was scheduled for cataract surgery and did not have glaucoma or other systemic disease.

Patients visiting the glaucoma clinic of the Research Institute of Ophthalmology had a detailed workup sheet including: 1- History: risk factors as family history of blindness or visual loss from different diseases. Previous history of increase in intraocular pressure or chronic steroid use and medical problems. 2Complete ocular examination: each subject underwent a detailed ophthalmologic examination including: best corrected visual acuity, slit lamp biomicroscopy and applanation tonometry. Gonioscopy to asses the anterior chamber angle and dilated fundus examination with special attention to the optic nerve head. 3- Baseline documentation of the optic nerve: image analysis and meticulous drawing for diffuse narrowing of the neuroretinal rim or focal narrowing or notching, nerve fiber defects, disc hemorrhages, asymmetry of optic nerve cupping \& or vertical elongation of the cup. 
Automated VF testing (Humphrey) for early: superior or inferior nasal step, superior or inferior arcuate defect, generalized depression, paracentral loss or late: temporal or central island of vision with advanced disease.

Patients with other ophthalmic conditions such as angle closure, or secondary glaucoma, trauma or systemic diseases like diabetes were excluded. Patients with previous laser surgery or history of intraocular surgery were also excluded. None of the patients smoked, had special diets or were taking antioxidant vitamins, such as tocopherols, or ascorbic acid or non steroidal anti-inflammatory agents.

\section{Surgical technique \&Sample collection:}

Aqueous humor samples were carefully collected at the beginning of surgery through a paracentesis, using a 27- gauge needle on a tuberculin syringe under an operating microscope with special care to avoid blood contamination. Standard trabeculectomy with fonix-based cojunctival flap was done after reformation of the anterior chamber by aqueous. Half thickness square scleral flap was dissected. Sclerostomy at sclerolimbal junction was perfomed, then a block of sclerolimbal tissue was removed with Vannas scissors. Periperal iridectomy was then performed. Suturing scleral flap with fixed sutures and assessment of flaps by injecting balanced salt solution through the paracentesis. Closure of the conjunctiva. Post operative subconjuntival steroid and antibiotics. Samples were rapidly frozen at $-70 \circ \mathrm{C}$ until assayed.
Determination of aqueous PAI1: by an enzyme linked immunosorbent assay (ELISA) which is a monoclonal antibody based assay, specific for the active form of PAI-1 which is captured by coated tPA. (HYPHEN BioMed ) ${ }^{(13)}$.

Total aqueous protein was determined using the Bradford method (14). This is a widely used sensitive colorimetric method that quantifies proteins based on the principle of protein dye binding.

Determination of aqueous TGFB2: by an enzyme linked immunosorbent assay (ELISA) (Quantikine, R\&D System Inc) ${ }^{(\mathbf{1 5})}$.

\section{Statistical analysis:}

Data was expressed as mean \pm SD. The groups were compared using the Student's-t test .The degree of association between the variables was assessed using Pearson's correlation coefficient (r), where values of $\mathrm{p}<0.05$ were considered significant.

\section{RESULTS}

Table I shows the mean \pm SD of PAI-1 (ng/ml), total protein $(\mathrm{ng} / \mathrm{ml})$ and TGFB2 (pg/ml) levels in aqueous of senile cataract patients and glaucoma patients.

There was a significant increase in PAI-1 levels in aqueous of group2 (early primary open angle glaucoma) patients when compared with cataract patients of group $1,4.2 \pm 0.33 \mathrm{ng} / \mathrm{ml}$ and $1.96 \pm 0.47 \mathrm{ng} / \mathrm{ml}$ respectively $(\mathrm{p}<0.05)$. Also there was a significant increase in PAI-1 levels in aqueous humor of group 3 (late primary open angle glaucoma) patients when compared with cataract patients of group1, 
$5.21 \pm 0.38 \mathrm{ng} / \mathrm{ml}$ and $1.96 \pm 0.47 \mathrm{ng} / \mathrm{ml}$ respectively $(\mathrm{p}<0.01)$. PAI-1 levels were significantly higher in group 3 compared to group $2(\mathrm{p}<0.05)$.

There was a significant increase in total protein levels in aqueous of group 2 (early primary open angle glaucoma) patients when compared with cataract patients of group1, $77.5 \pm 3.8 \mathrm{ug} / \mathrm{ml}$ and $52.9 \pm 2.3 \mathrm{ug} / \mathrm{ml}$ respectively $(\mathrm{p}<0.05)$. Also there was a significant increase in total protein levels in aqueous humor of group 3 (late primary open angle glaucoma) patients when compared with cataract patients of group, $77.9 \pm 4.9 \mathrm{ug} / \mathrm{ml}$ and $52.9 \pm 2.3 \mathrm{ug} / \mathrm{ml}$ respectively $(\mathrm{p}<0.05)$. No significant difference between group $2 \&$ group 3 was detected.

There was a significant increase in TGFß2 levels in aqueous of group 2 (early primary open angle glaucoma) patients when compared with cataract patients of group1, $3.03 \pm 0.41 \mathrm{pg} / \mathrm{ml}$ and $1.6 \pm 0.12 \mathrm{pg} / \mathrm{ml}$ respectively $(\mathrm{p}<$ $0.005)$. Also there was a significant increase in TGFß2 levels in aqueous humor of group 3 (late primary open angle glaucoma) patients when compared with cataract patients (group 1) $4.21 \pm 0.3 \mathrm{pg} / \mathrm{ml}$ and $1.6 \pm 0.12 \mathrm{pg} / \mathrm{ml}$ respectively $(\mathrm{p}<0.05)$. TGFß2 levels were significantly higher in group 3 compared to group2 $(\mathrm{p}<0.05)$.

There was a significant positive correlation between total protein \& PAI-1 in both glaucoma groups, $r$ $=0.52(\mathrm{p}<0.05) \& \mathrm{r}=0.8(\mathrm{p}<0.01)$ (fig. 1, 2). Also a significant positive correlation between PAI-1 \& TGFß2 was detected in both glaucoma groups, $\mathrm{r}=0.72 \& \mathrm{r}=0.67(\mathrm{p}<0.01)$ (fig. 3, 4).

Table (1): Aqueous levels of PAI-1, total protein and TGFB2 in senile cataract and glaucoma patients ( mean \pm SD).

\begin{tabular}{|c|c|c|c|c|c|c|}
\hline & \multirow{2}{*}{$\begin{array}{c}\text { Senile } \\
\text { Cataract } \\
\text { Group } 1 \\
\mathbf{N}=10\end{array}$} & \multirow{2}{*}{$\begin{array}{c}\text { Early } \\
\text { glaucoma } \\
\text { Group } 2 \\
\mathbf{N}=10\end{array}$} & \multirow{2}{*}{$\begin{array}{c}\text { Late } \\
\text { glaucoma } \\
\text { Group3 } \\
\mathbf{N}=10\end{array}$} & \multicolumn{3}{|c|}{ p value } \\
\hline & & & & $\begin{array}{c}\text { Group1 } \\
\& \\
\text { Group } 2\end{array}$ & $\begin{array}{c}\text { Group1 } \\
\& \\
\text { group } 3\end{array}$ & $\begin{array}{c}\text { Group2 } \\
\& \\
\text { Group3 }\end{array}$ \\
\hline PAI-1 (ng/ ml) & $\mathbf{1 . 9 6} \pm 0.47$ & $4.2 \pm 0.33$ & $\mathbf{5 . 2} \pm 0.38$ & $\mathrm{p}<0.05$ & $\mathrm{p}<0.001$ & $\mathrm{p}<0.05$ \\
\hline $\begin{array}{l}\text { Total } \\
\text { protien(ug/ml) }\end{array}$ & $\mathbf{5 2 . 9} \pm 2.3$ & $77.5 \pm 3.8$ & $77.9 \pm 4.9$ & $\mathrm{p}<0.05$ & $\mathrm{p}<0.05$ & NS \\
\hline TGF B2( pg/ml) & $1.6 \pm 0.12$ & $\mathbf{3 . 0 3} \pm_{0.41}$ & $4.2 \pm 0.3$ & $\mathrm{P}<0.005$ & $p<0.05$ & $p<0.05$ \\
\hline
\end{tabular}

$\mathrm{P}<0.05$ is considered significant. 

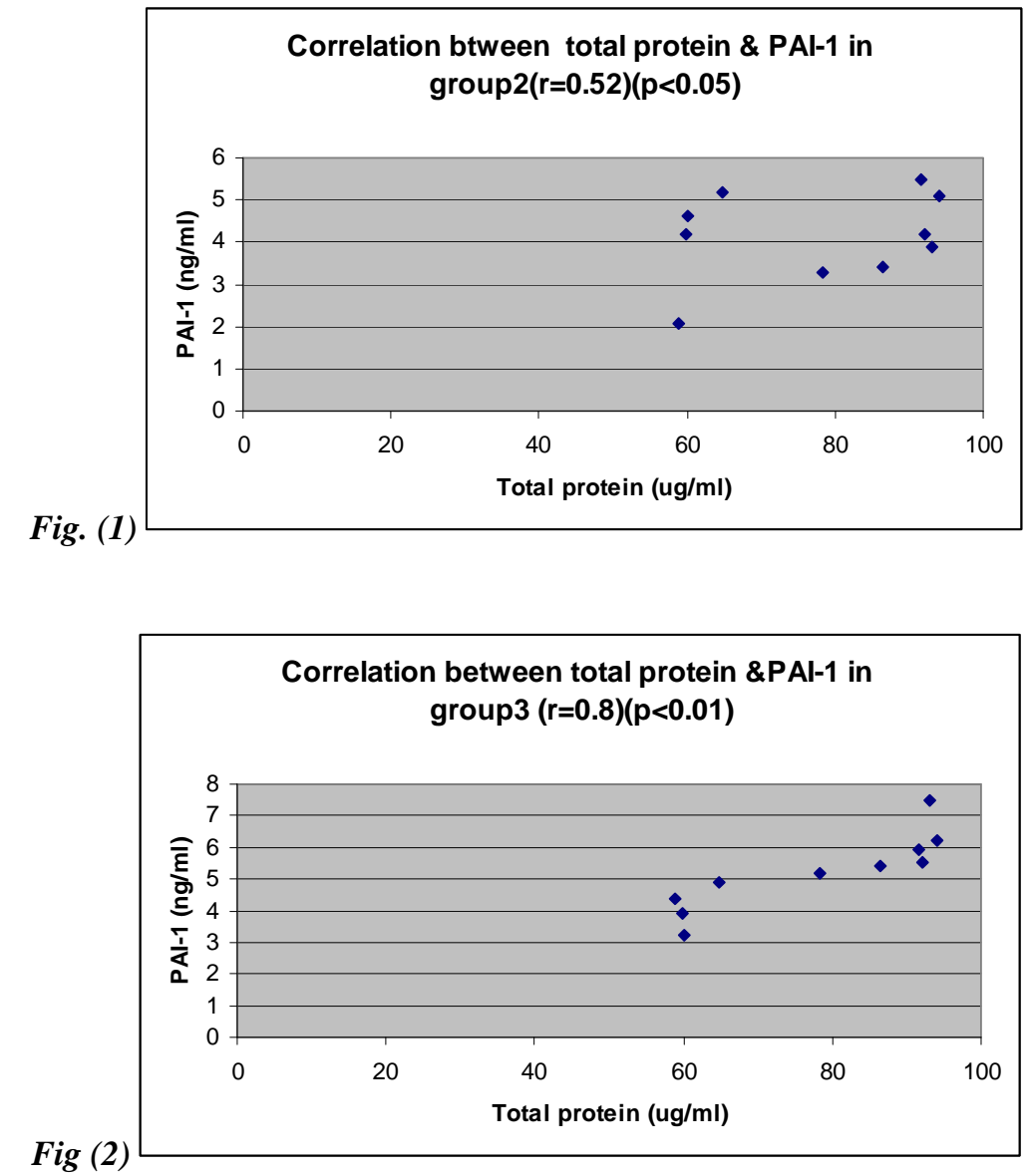

Fig. (3)

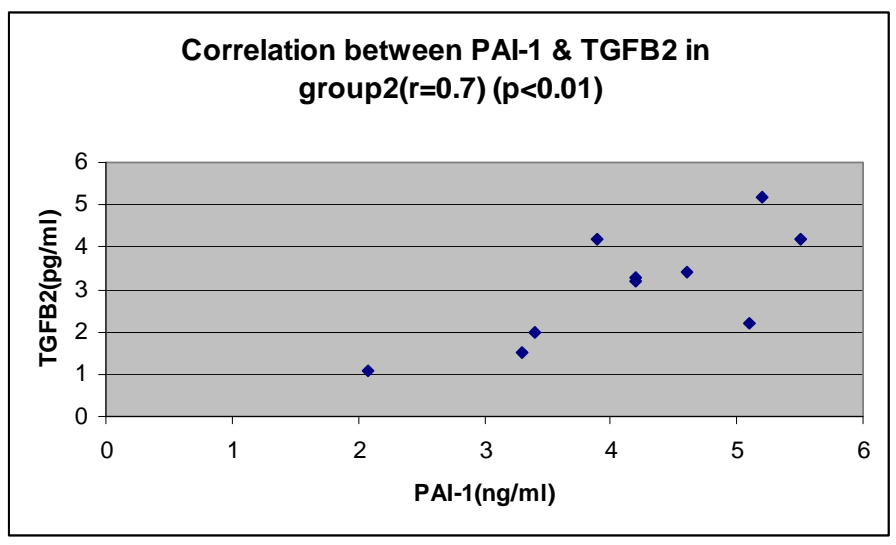




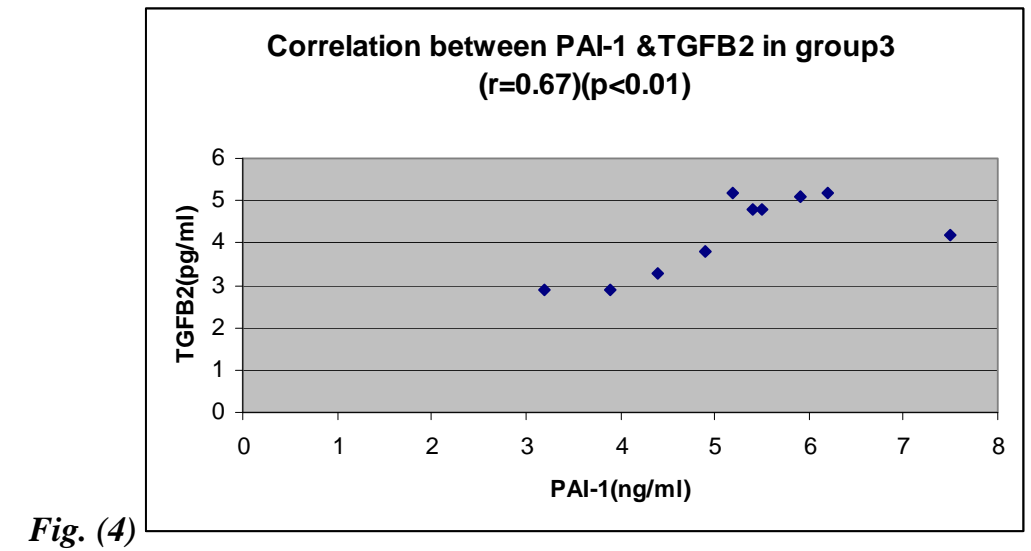

\section{DISCUSSION}

One potential causative factor for the POAG-associated increase in intraocular pressure (IOP) is compromised outflow facility of aqueous humor (AH) through the trabecular meshwork (TM). A disproportionate accretion of ECM occurs in the TM region of POAG eyes, and this buildup is believed to impose greater resistance to $\mathrm{AH}$ outflow, resulting in increased $\mathrm{IOP}^{(\mathbf{1 6})}$.

The results of this study demonstrated that the aqueous levels of PAI- 1 and total protein were significantly elevated in both glaucoma groups compared to cataract group. Also there was a significant association between the levels of PAI1 and total protein. This is consistent with the results of Dan et al. ${ }^{(17)}$ who suggested that enhanced PAI-1 synthesis in the ciliary body may contribute to outflow resistance and IOP elevation.

PAI-1 inhibits the activity of both tissue plasminogen activator (tPA) and urokinase plasminogen activator (uPA). Both tPA and uPA catalyze the conversion of plasminogen into plasmin, a key intermediate in the fibrinolytic cascade. Plasmin, in addition, is known to promote the conversion of certain pro matrix metalloproteinases (MMPs) into their active ECM-degrading forms ${ }^{(\mathbf{1 8})}$. This was prompted by the findings of Masos et $\mathrm{al}^{(\mathbf{3})}$ who found that in the adult murine eye, the PAI- 1 gene is expressed exclusively in the apices of the ciliary body processes and accordingly PAI-1 activity was detected in the aqueous humor. This could be possible for the human eye as it was showed that human ciliary body epithelial cells could express groups of several genes, including genes encoding protease inhibitors ${ }^{(\mathbf{1 9})}$. This distinct localization implies that PAI-1 may play a role in the anterior chamber and trabecular meshwork.

Therefore, an increase in PAI-1 levels would be expected to lead to a reduction of activated MMP levels and, conceivably, accumulation of 
pro-MMPs within responsive tissues. Specifically up regulation of PAI-1 gene in the ciliary epithelium could shift the proteolytic balance towards inhibition and might also interfere with cell adhesion ${ }^{(\mathbf{2 0})}$.

The subgroup analysis of glaucoma patients showed that PAI-1 levels were highest in patients with late-open angle glaucoma as Dan et $\mathrm{al}^{(17)}$. They found that increased levels of PAI-1 in the aqueous humor glaucoma patients may contribute to sclerosis of the juxtacanilicular tissue and thereby to outflow obstruction and glaucoma pathogenesis ${ }^{(21)}$.

Also, this study has showed significant higher levels of TGF-B2 in aqueous humor collected from POAG patients compared to cataract patients. . In agreement with these results are Ozcan et al. ${ }^{(22)}$ and Picht et al. ${ }^{(23)}$, who postulated that TGF- $\beta$ is a cytokine that alters extracellular matrix (ECM) metabolism, and excess $\mathrm{ECM}$ has been proposed to increase aqueous outflow resistance in the trabecular meshwork (TM) of glaucomatous eyes. It has been shown that in vitro treatment of cultured human TM cells with TGFß2 leads to changes in gene expression, including genes that may contribute to ECM accumulation ${ }^{(22)}$.

This study showed a positive correlation between TGF- $\beta 2$ and PAI1 in both glaucoma groups which agreed with the findings of Debra et al (24). They found that TGFß2-treated human TM cells altered the production of the enzymes promatrix metalloproteinase-2 and plasminogen activator inhibitor (PAI)-1. Elevated levels of $\mathrm{AH}$ TGFß2 thus may have the dual effect of both a direct increase in TM production of ECM components (e.g., fibronectin) and an enhanced production of gene products inhibiting ECM degradation e.g., PAI1. The latter has potential effects on ECM accumulation and elevated PAI1 levels may have other consequences that also contribute to the pathogenesis of glaucoma ${ }^{(19)}$.

It has been reported previously that a progressive loss of human TM cells occurs with normal aging ${ }^{(25)}$. The rate of this loss appears to be accelerated in POAG eyes. The underlying mechanism(s) for this loss is not yet known although, in addition to a decrease in replicative potential, it has been attributed to a variety of factors that affect TM cell migration and/or adhesion, including increased phagocytosis, oxidative stress, myocilin, and the presence of chemoattractants within the aqueous humor ${ }^{(26)}$.

\section{Conclusion \& Recommendation:}

The findings presented in this study suggest that enhanced PAI-1 synthesis in the ciliary body may contribute to outflow resistance and IOP elevation. This raises the possibility of considering intraocular PAI-1 as a target for the design of new glaucoma drugs.

\section{REFERENCES}

1. Tiesch JM, Sommer A, and Katz J, (1991): Racial variations in the prevalence of primary open angle glaucoma. JAMA ,266:369374 .

2. Yun AJ, Murphy CG, and Alvardo JA, (1999): Proteins secreted by human trabecular cells, glucocorticiods and other 
effects. Ivest. Opthalmol. Vis. Sci. 30: 2012-2022.

3. Masos T, Dan DJ and Misikin CG (2000): Plasminogen activator inhibitor is located in the adult rodent eye exclusively in the tips of the ciliary process . Invest. Opthalmol .Vis. Sci. 41, 1006- 1011 .

4. Loskutoff DJ (1991): Regulation of PAI-1 gene expression . Fibrinolysis , 5, 197-209.

5. Kohler Hp and Grant PG (2000): Plasminogen activator inhibitor type -1 and coronary artery disease. N. Eng. J. Med. $342,1792-1801$.

6. Vassila JD, Sappino AP and Relin D (1991) :The plasminogen activator inhibitor system . J. Clin .Inves. 98, 1067- 1072 .

7. Czkay RP, Aertgeets $K$ and Lostkutoff DJ (2003): plasminogen activator inhibitor -1 detaches cells from extracellular matrices by inactivating integrins. J. Cell.Biol. 160, 781-791 .

8. Koeing W (1998): Haemostatic risk factors for cardiovascular disease. Eur. Heart J.19 (suppl c)C39-C43.

9. Festa A , Agustino RG Tracy RP and Hafiner SM (2002): Elevated levels of acute phase proteins and plasminogen activator inhibitor-1 predict the development of type 2 diabetes . Diabetes, 51,1131-1137.

10. Picht $G$, Welge-Liessen $U$ and Grehn F (2001): Transforming growth factor B2 levels in aqueous humor in different types of glaucoma. Grafes Arch.Clin. Exp. Opthalmol. 239, 199-207.
11. Dunker N, and Krieglstein $K$. (2000): Targeted mutations of transforming growth factor- $\beta$ genes reveal important roles in mouse development and adult homeostasis. Eur. J. Biochem. ;267:6982-6988.

12. Kottler UB, Junemann AGM, Aigner T, Zenkel M, Rummelt C, Schlotzer-Schrehardt U. (2005): Comparative effects of TGF- $\beta 1$ and TGF- $\beta 2$ on extracellular matrix production, proliferation, migration, and collagen contraction of human Tenon's capsule fibroblasts in pseudoexfoliation and primary open-angle glaucoma. Exp. Eye. Res;80:121-134.

13. Declerck PG, Allessi MC, and Colen D (1998): Measurement of plasminogen activator inhibitor in biological fluids with a murine monoclonal antibody based enzyme linked immunosorbent assay. Blood, 71, 220-225.

14. Bradford MM (1976): A rapid and sensitive method for the quantitation of microgram quantities of protein utilizing the principle of protein -dye binding. Anal. Biochem. 72,248-254.

15. Barnard JA, Lyons RM, Moses HL. (1990): The cell biology of transforming growth factor beta. Biochim. Biophys. Acta. 1032:7987

16. Lee WR, and Grierson I. (1974): Relationships between intraocular pressure and the morphology of the outflow apparatus. Trans Ophthalmol. Soc. UK. 94:430-449

17. Dan J, Belyea D, Gertner G, Leshem I, Lusky M, Miskin R. 
(2005): Plasminogen activator inhibitor-1 in the aqueous humor of patients with and without glaucoma. Arch. Ophthalmol.;123:220-224.

18. Wu Q, Zhao Z. (2002): Inhibition of PAI-1: a new antithrombotic approach. Curr. Drug. Targets. 2:27-42

19. Pang IH, Hellberg PE, Fleenor DL, Jacobson N, Clark AF. (2003): Expression of matrix metalloproteinases and their inhibitors in human trabecular meshwork cells. Invest.Ophthalmol.Vis Sci;44:164-169.

20. Bradley JMB, Kelley MJ, Zhu XH, Anderssohn AM, Alexander JP, Acott AS (2001): Effect of mechanical stretching on trabecular matrix metalloproteinases. Invest. Ophthalmol. Vis. Sci; 42:15051513.

21. Czakey RPand Loskutoff DJ. (2004): Unexpected role of plasminogen activator inhibitor 1 in cell adhesion and detachment. Exp. Biol. Med. 229:1090-1096

22. Ozcan AA, Ozdemir $\mathbf{N}$ and Canataroglu A (2004): The aqueous levels of TGF-beta2 in patients with glaucoma. Int. Ophthalmol. Jan;25(1):19-22

23. Picht G, Welge-Luessen $U$, Grehn F and Lütjen-Drecoll E. (2001): Transforming growth factor beta 2 levels in the aqueous humor in different types of glaucoma and the relation to filtering bleb development. Graefes Arch. Clin. Exp. Ophthalmol.;239:199-207

24. Debra L. Fleenor, Allan R. Shepard, Peggy E. Hellberg, Nasreen Jacobson, Iok-Hou Pang, and Abbot F. Clark (2006): TGFß2-Induced Changes in Human Trabecular Meshwork: Implications for Intraocular Pressure. Investigative Ophthalmology and Visual Science.; 47:226-234.

25. Wentz-Hunter $K$, Kubota $R$, Shen X, Yue BY. (2004): Extracellular myocilin affects activity of human trabecular meshwork cells. J. Cell Physiol. 200:45-52

26. Hogg P, Calthorpe M, Batterbury M, Grierson I. (2000): Aqueous humor stimulates the migration of human trabecular meshwork cells in vitro. Invest. Ophthalmol. Vis. Sci. 41:1091-1098. 


\title{
مثبط منشط البلازمينوجين - 1 وعامل النمو المتحول ب r فى سائل الذزانة الأمامية للمرضى المصابين وإلغير مصابين بمرض المياه الزرقاء
}

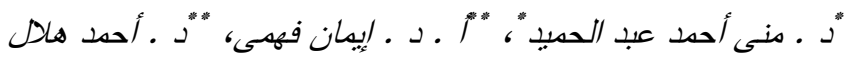

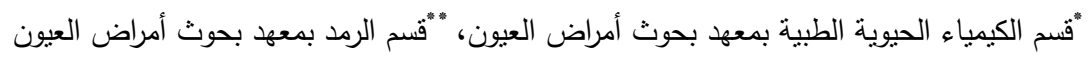

يهدف هذا البحث دراسة دور مثبط منثط البلازمينوجين - 1 وعامل النمو المتحول ب r في سائل

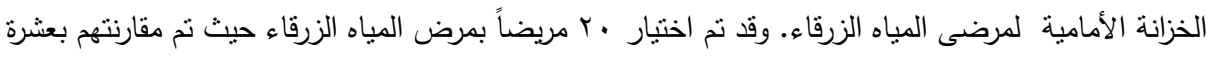

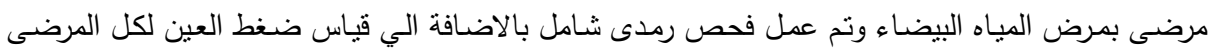

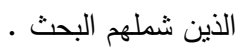

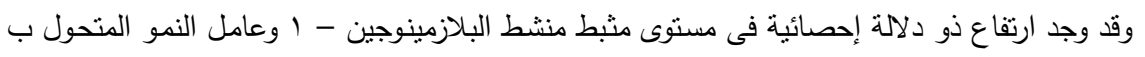

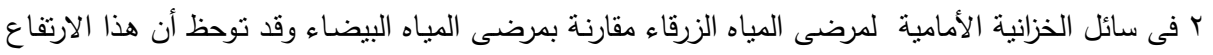
أكثر وذو دلالة إحصائية فى مرضى المياه الزرقاء المتأخرة عنه في مرضى المياه الزرقاء الحئية الحديثة .

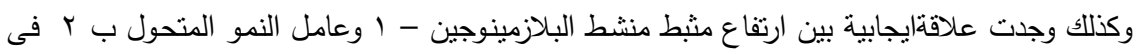

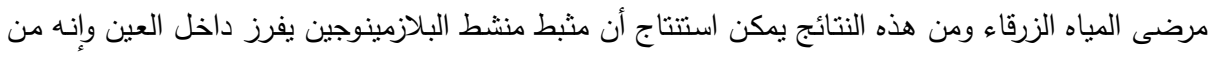
أهم الأسباب المؤدية لحدوث مرض المياه الزرقاء . 